\title{
Intellectual property rights in the Ecuadorian music industry: digital media
}

\author{
Derechos de propiedad intelectual en la industria \\ musical ecuatoriana: Medios digitales
}

\section{Juan Sebastián Aguirre Navarrete}

Independent researcher

City: Quito

Country: Ecuador

Original article (research note)

RFJ, No. 8, 2020, pp. 249-267, ISSN 2588-0837

\begin{abstract}
Inside the panorama of the music industry have been generated by several legal relationships. Generally, the artist is only concerned with expressing his ideas through songs, based on deep feelings or experiences that have marked him, but he does not realize that he is in a very complicated legal relationship when privatizing his creations. Many artists throughout their careers legal issues related to the use of copyrights in their discography; a very recent case is that of the famous artist Taylor Swift where the problem lies in the snatching of their copyright author. This miscellaneous article focuses on identifying the regulations with which the Ecuadorian government protects intellectual property rights in the Ecuadorian music industry in the current digital era. As a final result, we state that Ecuadorian legislation has an optimal regulation that encourages the operation of the intellectual property regime in Ecuador. However, artists do not choose to enter this industry due to the low performance it has in our country.
\end{abstract}

KEYWORDS: Digitization, recording industry, music, copyright, intellectual property 
RESUMEN: Dentro del panorama de la industria musical, se ha generado un sin número de relaciones jurídicas. Generalmente, el artista solo se preocupa por expresar sus ideas a través de canciones, basándose en sentimientos profundos o experiencias que lo han marcado, pero no se percata de que se encuentra en una relación legal muy compleja al momento de privatizar sus creaciones. Muchos artistas a lo largo de su carrera se han visto envueltos en diversos problemas sobre el uso de derechos de autor en su discografía, un caso muy reciente es el de la famosa artista Taylor Swift en donde el problema radica en el arrebato de sus derechos de autor. Este artículo se enfoca en identificar las regulaciones con las que el estado ecuatoriano protege los derechos de propiedad intelectual en la industria musical ecuatoriana, que se desarrollan en el entorno digital. Como producto de esta investigación se puede deducir que la legislación ecuatoriana cuenta con una regulación optima que incentiva el funcionamiento del régimen de propiedad intelectual en el Ecuador, sin embargo, los artistas no optan por introducirse a esta industria por el bajo rendimiento que esta tiene en nuestro país.

PALABRAS CLAVE: Digitalización, industria discográfica, música, derecho de autor, propiedad intelectual.

\section{INTRODUCTION}

Musical works are undoubtedly one of the essential categories of works for copyright. For many years, musical authors have exercised high power in the process of claiming copyright. However, recognition was granted to the authors by the Berne Convention for the protection of literary and artistic works of 1886. Then, only the authors of the lyrics and the music of the songs were sheltered, leaving aside the interpreters of musical works, who from the signing of the 1961 Rome Convention recognized these rights with the name of neighbouring rights or neighbouring rights. (Ríos, 2011) 
The development and impact of the music industry have not had significant relevance in Ecuador, even though there is a variety of Ecuadorian artists who can easily be great international and even world exponents within this industry. It leads us to wonder about what is the leading cause to understand why in our country music is not in constant development? Although thanks to the various digital platforms such as Spotify, tidal, iTunes, among others, the artists have more facility for distributing their music around the world and thus be able to reach a broader audience.

Therefore, the primary intention of this miscellaneous article is to identify the regulations with which the Ecuadorian government protects intellectual property rights in the Ecuadorian music industry and that are developed in the digital environment. Likewise, this article will serve as a contribution so that the subjects of law which are involved in this industry know their intellectual property rights.

In the first part, we will go through history to analyze the impact that digital technology has had on the music industry, the transformations in this regard and the evolution in the industry, as a result of technological advances, will be explained.

Subsequently, it will begin to conceptualize copyright and related rights that are presented outside the music industry, this in order to have a clear and precise knowledge, which will serve as a basis to identify the problem regarding the protection of rights author in Ecuador.

Later, it is analyzed who are the subjects of law in this industry, what is the role they play, what are the intellectual property rights attributed to them and what legal act supports them. Next, the various mechanisms that protect the copyrights regulated by Ecuadorian legislation will be identified. Finally, conclusions are drawn seeking to encourage artists working for the Ecuadorian Record Industry. 


\section{IMPACT OF DIGITAL TECHNOLOGY ON THE MUSIC INDUSTRY}

In this part of the article, we will analyze the impact and importance that digital technology has had in the music industry in the last four decades. We will also detail how this industry has evolved and what changes have arisen thanks to technology. It will help us to know how technology has been the product of constant changes that have contributed significantly to human development.

In the late 19th century, Thomas Alva Edison, an American scientist and businessman, invented the phonograph. The phonograph was the most common first device to record and reproduce sounds from the 1870 s to the 1880 s. This device made it easy and fast to record a musical copy multiple time. With the help of this device, the foundations for industrializing the music sector were accentuated. (Arias, 2013, p. 36)

Later in 1982, compact discs were created. Thanks to these, the different users were able to count on a new and improved digital audio, in addition to the fact that they encouraged the commercialization of record formats with a higher economic value that gradually grew. Consequently, the artists and the record companies perceived an increase in their income from the sales of each CD. According to Yudice (2007): "The technologies of the last three decades have influenced everyone's experience, and not only that of the musicians or fans of this or that type of music". (p.18)

In the 1990s, users and listeners had a wide variety of photographic collections. It was not only due to the replacement of the old compact disc formats, but it was also thanks to the double cassette audio equipment in which entire albums could be copied. These factors were essential to demonstrate the tremendous technological advance in the record sector since they allowed storing and reproducing the various songs. (Palmeiro, 2004, p. 4) 
All these inventions reached their maximum splendour in the mid-1990s when the development of digital technology and the beginning of multimedia were of vital importance so that computers could reproduce and store the music on compact discs. (Alexander, 2002, p. 153). Likewise, the development of these devices was one of the essential innovation processes of the 20th century concerning the music industry. From that century on, people could listen to their favourite songs on various technological devices, both on sound equipment or through a television screen (Barreto, 1998, p. 21). On the other hand, the digitization of audiovisual content made it possible to include videos and multimedia material on discs using CD-ROM technology. (Pucci del Río, 2008, p. 68)

However, at that time, technological developments in digital music, such as digitization of compact discs and multimedia advances, were still part of the traditional model of the recording industry and did not threaten a complete structural change. It is because of Phonogram revenues left vast profits to sign contracts with great artists of the medium, causing this industry to remain in the physical distribution of compact discs. The same discs contained the musical tracks. (Moyon and Lecocq, 2010, p. 43)

Later, thanks to the arrival of the burners (which had very advanced digital technology), a compact disc with the same sound quality as the original disc could be copied at a low cost, which consequently brought a threat to the traditional model of the record business. (Ochoa, 2003, p. 21)

At the end of the seventies, portability and the new facilities brought by the creation of the cassette and the walkman were the new protagonists of the music industry. These inventions allowed users to listen to their favourite songs with greater comfort. Gradually, thanks to these portable devices, the practices of listening to music were changed, turning them into a mobile experience. (Yudice, 2007, p. 47) 
In 1998 Diamond Multimedia created the Rio PMP 300, a small portable device, the size of a cassette, with the ability to store mp3 song formats. The Rio PMP 300 revolutionized the recording industry, since it went from listening to a physical compact disc to listening to digitized immaterial files, in order to have greater functionality in the experience of listening to music. (Moreau, 2013, p. 24)

In October 2001, the iPod was invented, a device created by the computer company Apple, a company that created the digital music platform iTunes in the same year, which was very successful in the market. With this, an alliance was established between the digital technology sector and the recording industry. The creators of the iPod were Steve Jobs, Phil Schiller and Jon Rubinstein, who criticized the operation of the Rio PMP 300 and therefore decided to launch an improved product (Isaacson, 2011, p. 483).

Estela Civano (2003) affirms: "since 1999, pushed by the computer manufacturing companies, CD readers began to reach the markets with the additional capacity to record". (pp. 3-4)

The advancement of mobile technology and the ease of access to formats such as mp3 have been a significant scientific development in the history of the recording industry. Regarding this, Pablo Pucci Del Río (2008) points out: "regarding the digital area, it can be affirmed that the greatest revolution in the way people listen to music, since the Sony Walkman in the eighties, corresponds to the iPod of Apple”. (p. 87)

Digital technology innovation has been made possible through cooperation between record labels and the telecommunications sector. With these cooperations, the development of new business models for mobile phone companies was achieved. Martín Raposo (2008) alludes to this development in his work, "New look on the music industry": 
The most recent changes, mainly related to cellular telephony and its possibility of downloading music files in a short time, either to listen to it or to use it to personalize the device, allow us to imagine a growth scenario for the industry. (p. 1)

Jonathan Benassaya and Daniel Marhely created in 2006 a platform of French origin called Deezer, which allowed users to easily access a catalogue of thousands of songs, via cell phone or computer, through a free plan with advertising or a service Premium without advertising with a value of 7 to 15 dollars per month, depending on the country where the user is located. (Arango, 2016)

Soon other streaming platforms similar to Deezer were born, such as Spotify. A digital music platform created in Sweden in 2008, by Daniel Ek and Martin Lorentzon. Spotify brings with it new functions: it offers the possibility of creating personalized playlists which can be shared through social networks, meet new musical trends and consult biographies of favourite bands and artists. (López, 2014, p. 57)

Thanks to these streaming services, access to music were enabled from any mobile phone, paying a monthly fee through the cell phone bill. In the same way, these advances contributed to the progress of digital technology and electronic commerce, since in Latin America most people do not have credit cards or do not choose to make payments with their cards for fear of becoming victims of scams or robberies. (Cobo, 2008, p. 6)

Then, digital technology transformed the traditional business model in the record and music industry, completely changing the way music is distributed and produced in record companies. Today with the help of telecommunications, the way of listening to music has been improved, making it reach any corner of the planet. With the different technological advances, already mentioned, it was possible to provide more 
magnificent entertainment to users, allowing them to interact with their mobile devices and listen to their favourite music at any time.

\section{COPYRIGHT AND RELATED RIGHTS IN THE MUSIC INDUSTRY}

The concept of copyright and its classification, in the same way, we will present each of the rights that the different types of authors have in the Ecuadorian music industry. Following is a brief definition of related rights, this will help us later, to determine the degree of affectation or protection of copyright for musical works distributed in digital media. Likewise, copyright is a legal area that, through a set of norms, protects the rights of creators of artistic and literary works by recognizing a series of personal and patrimonial prerogatives called moral and patrimonial rights. Respectively. (Martínez, 2006)

The composers-composers of a musical track have a variety of copyrights that include both the heritage sphere and the moral aspects of these rights. By economic rights, we understand those by which the authors can economically exploit their work. Due to the patrimonial content of these rights, the composer-authors can assign, transfer, license, and others. The ownership of these in whole or in part, according to the will of the rights-holder. (Martínez, 2006)

Following the Ecuadorian Intellectual Property Law, better known as INGENIOS (2016), regarding the regulation of economic rights, the author of the work, has the following rights:

1. The right of reproduction of the work: It is a right employing which the authors can authorize or prohibit the fixation of a work in material support; as well as making copies of this work in whole or in part, whether by any physical or digital means. 
2. The right of distribution: It is the right of the author-composers to authorize or prohibit any type of exploitation of the work, whether through sale, rental, leasing or any other way by which copies are distributed. of the work.

3. The right of public communication: It is the right of the authors to carry out, authorize or prohibit any type of disclosure of the musical work to a plurality of people gathered or not in a specific place without the prior non-existence of the distribution of copies.

Likewise, in the law mentioned above, various economic rights are granted to the author, such as:

1. The right of paternity: It is the right of the authorcomposer to always and at all times be recognized as the author of the work. Even when a work is known to the public, the authorship of the person who created it must be identified in the way the author estimates, either through its name or pseudonyms.

2. The right of integrity: It consists of the authority that all authors have that their work is not deformed or altered, in such a way that it affects their interests and reputation.

3. The right of unpublished: The author and composer's right to keep his work unpublished, that is, not to make his work known to the public.

4. The right of modification: Once the work has been published, the author has the right to make changes that he considers relevant. In this case, the author must pay the publisher or producer the costs and losses caused by the modification of the work. 
5. The right of withdrawal or withdrawal: It is the right of the author to withdraw his work from circulation at any time or suspend its use. Here, in the same way, as in the case of modification, the author must indemnify the publisher or producer for the losses caused by the withdrawal of the work from the market. (Ingenios Code, 2016)

On the other hand, related rights are rights parallel to copyright and refer to the protection of artists, performers and performers concerning their activities. In some countries such as the United States and England, they are called "Related Rights" or similar rights, while in places like France they are called "Droits Voisins" or neighbouring rights. (Ficsor, 2002)

Altamirano (2008) notes that:

It is essential to explain that copyright belongs to the creator of the musical work. They have the exclusive right to restrict the reproduction of the work, but they can license, transfer or sell part or all of it. It has led to the formation of companies that collectively collect and distribute rights through the application of network economies. Revenue is distributed to agents who are entitled to obtain agency rights, and an agreement is signed with a foreign copyright collection association to obtain locally obtained royalties.

Copyright is relevant to have mastery of the creation of the musical work; without these rights, the creator cannot obtain benefits, whether thoroughly artistic or economic from its creation. These rights are protected by the Ecuadorian government in order to guarantee that whoever created the music track can claim their rights if third parties appropriate or obtain economic benefits from the work. 


\section{SUBJECTS OF LAW IN THE MUSICAL INDUSTRY}

In the music market we have multinational companies that are located around one of the most lucrative and fastgrowing entertainment businesses in the world economy, these big companies are known as "the big four", and they lead above $70 \%$ of the global market of the music industry. In comparison, the other independent companies reach $28 \%$ of this market. These large multinational companies are Universal Music Group with 26\%, Sony-BMG Music Entertainment with 22\%, EMI Group with 13\% and finally Warner Music Group with 11\%. (Altamirano, 2008)

However, despite their importance in being important in the global context of the music industry, record companies are not the only players in the music market. The other subjects of rights in the industry are among others the manufacturers of music equipment, the organizers of musical concerts, each with their contribution and in search of their benefit, which, as in all industries, are geared to give movement and generate wealth. (Altamirano, 2008)

On the other hand, the music industry is developed with various agents under contractual relationships that grant legal certainty, protecting artists and other holders from improper exploitation by third parties in an industry that is increasingly diverse and evolving. The contractual relationships typical of the music industry revolve around two underlying contracts: the one for music publishing and the one for inclusion in the phonogram, without taking into account the service provision contracts, which could be concluded between the artist's manager and a promoter. concerts, which will serve as a guideline for the regulation of commercial relations between the subjects of law. (Álvarez, 2014)

These legal acts must be valid in all contracts, and are mandatory under the principle of "pacta sunt servanda" 
since the agreements reached by the parties must be clearly defined in aspects related to the contractual object, the terms of fulfilment of the benefits and the affectation of the economic rights involved. (Ríos, 2011)

There is a figure in charge of protecting the rights of authors such as music publishers. The work of these entities is to monitor and protect intellectual property rights. One of the main functions of music publishers is to claim copyright income that may not have come to the creator of the musical work. In this transfer of economic rights, the publisher will be responsible for the commercialization of the works. Thus, it is this entity that authorizes the record labels to take care of aspects such as recording, production or distribution. (ICAM, 2008)

The work of these companies is administrative tasks such as royalty control and payment to the authors. In this way, the artist keeps all his copyrights under guardianship to ensure the independence and integrity of his works. (ICAM, 2008)

According to Álvarez (2014), the agents that can potentially intervene in the chain of negotiations in the music industry are:

1. Author and composer: Both subjects are protected by copyright, however, for practical purposes, it is understood that the author of a song is the one who writes the lyrics, while the composer is the one who composes the melody. These two qualities can come together in one person without any problem, but it is common to find cases where the author of work needs the help of other individuals who assist him and contribute to the creative enrichment of it. (Ríos, 2011, p. 56) 
2. Performer: The performer is the lead musician who sings or plays the work on either a phonogram or live, while the performer is the accompanying musician.

3. Manager: Manager, or representative, is the person who controls the professional activities of the artist, that is, who is in charge of advising, supervising and managing the business. One of its most relevant functions is the negotiation of contracts in which the economic rights over the works could be affected.

4. Music editor: It is the person who, through an editing contract, is in charge of managing the economic exploitation of the rights of the author or composer, that is, of marketing the works and paying the royalties

5. Producer of phonogram: The producer, or production company, is the one who has the recording of the songs under his administrative and financial direction and has the resources to produce the phonogram or master.

6. Broadcasting organizations: They are the radio or television companies that emit and broadcast signals at a distance, destined for the public, that may contain images, sounds or both.

When creating and producing musical work, various subjects contribute to its creation. Each person, involved in the creation of the musical work, plays a fundamental role to shape the track ultimately, either producing the song's melody or singing it. These people are protected by law to receive benefits for their contribution to the song, either in the work of creation, production or interpretation of the musical work. 


\section{LEGAL PROTECTION OF THE AUTHOR IN THE DIGITAL ENVIRONMENT}

Musical tracks have characteristics corresponding to a private good, so these must be protected so that they are not susceptible to plagiarism or copying, and thus prevent third parties from obtaining benefits that can be perceived by publishing or selling musical works. Copyright is protected in a large number of countries around the world in order to protect human ingenuity and creativity. (Altamirano, 2008)

However, technological advances make copyright protection more and more complicated, the rapid proliferation of the Internet and the new digital age make it necessary for the recording industry to transform and seek to develop business models that facilitate the commercialization of its products. agile way. (Rodríguez, 2019)

Achieving the perfection and implementation of an adequate legal framework on copyright in each of the countries and also with both international agreements are very important in the digital scene because the Internet allows mobility across borders easily of content. (Flores, et al., 2018)

The Organic Code of the Social Economy of Knowledge, Creativity and Innovation is the legal framework that empowers the Ecuadorian State to assume the defence and protection of intellectual rights. This code, better known as INGENIOS, encourages investment in research and development regarding the protection of intellectual property rights. (Espinel Pacheco, 2017)

Article 559 of the Organic Code of the Social Economy of Knowledge, Creativity and Innovation (2016), establishes that: "The competent national authority in matters of intellectual rights shall exercise, ex officio or at the request of a party, inspection, monitoring and sanction functions to avoid 
and suppress infringements of intellectual property rights." It is the first real mechanism to sanction infringers who violate copyright. It is a process to determine whether or not there is an infringement of these rights and issue the stipulated sanction through resolution. (Rubio Tigasi, 2019)

In the same way, article 256 of the Organic Code of the Social Economy of Knowledge, Creativity and Innovation (2016), stipulates: "Whoever exploits a work, performance or execution, broadcast or phonogram must pay, as compensation, a surcharge of fifty for per cent on the rate, calculated for the entire time that the exploitation has been carried out." Here you can see another protection mechanism regarding copyright, which indicates that the person or group of people who violate and exploit copyright must financially compensate the owner of the right with fifty per cent of the fee throughout the estimated time of exploitation of the work. (Rubio Tigasi, 2019)

Ecuador has regulations that guarantee the protection of copyrights. However, technology is advancing rapidly, which will always require laws that adequately protect the author. Laws must evolve and transform the landscape of the music industry, in the digital environment, in order to ensure copyright.

\section{CONCLUSIONS}

Music is the primary form of entertainment worldwide. Music is found in each country since it has been captured from its ancestral roots and is a characteristic of many cultures originating in the world. With advances in technology, the traditional model of the music and record industry was utterly transformed. It made it easier for the different musical genres to reach different parts of the world, making it possible for a wide variety of people to listen to them. 
The Internet is a tool that offers better business opportunities for the music industry, especially for independent artists who are beginning to stand out in the media for themselves. Thanks to the digital platforms that have been created and have evolved, the distribution of music has been facilitated, through the new business model that is the streaming service or through online downloads. Achieving that different musical styles and artists increase their audience. Each person involved in the musical creation process has a variety of rights and obligations according to how significant the contribution was in creating the song. Each of these people is protected by law in order to safeguard their rights since they are in a contractual legal relationship.

The Ecuadorian music industry does not have a more significant impact internationally, even though there are many artists with enough talent to develop within this medium. What happens is that in the country, there is no greater motivation for artists to develop in the industry. The country has the optimal regulations to protect copyrights in the field of music creation, but artists are not motivated to fully function in this environment.

\section{REFERENCES}

Alexander, P. J. (2002). Peer-to-peer file sharing: The case of the Music Recording Industry. Review of Industrial Organization, 20(2), pp. 151- 161.

Altamirano, T. (2008). Perspectivas de transformación de la industria discográfica en el Ecuador. (Tesis de maestría). Quito: Universidad Andina Simón Bolívar, Sede Ecuador.

Álvarez Cabrera, S. (2014). El derecho de propiedad intelectual en la industria musical colombiana: Sujetos de derecho y protección jurídica. Revista Derecho Privado, (52), pp. $1-27$. 
Arango Archila, F. (2016). El impacto de la tecnología digital en la industria discográfica. Dixit, (24), pp. 36-50. https:// doi.org/10.22235/d.v0i24.1168

Arias Franco, E. (2013). La industria de la música independiente y su consumo cultural. Derecho a Comunicar. Revista Científica de la Asociación Mexicana de Derecho a la Información, 8, pp. 29-47.

Asamblea Nacional del Ecuador. Código Orgánico de la Economía Social de los Conocimientos, Creatividad e Innovación. (2016). RO. 899 de 9 de diciembre de 2016. Recuperado de: https://www.propiedadintelectual. gob.ec/wp-content/uploads/downloads/2019/ febrero/a_2_16_codigo_ingenios_febrero_2019.pdf

Barreto, A. (1998). The music industry: technology and intellectual rights. Law Technology, 31, 1, pp. 19-37.

Civano, E. C (2003). La industria discográfica y la migración de valor. En Jornadas Universitarias de Estrategia, Complejidad y Caos en las Organizaciones. Buenos Aires: Universidad de Buenos Aires.

Cobo, L. (2008). Latin Alternative? Billboard, 120(45), p. 6.

Espinel Pacheco, K. (2017). Ley código ingenios: afectación y beneficios para artistas ecuatorianos. Quito: Universidad de las Américas.

Ficsor, M. (2002). Gestión colectiva de derechos de autor y derechos afines. Ginebra: WIPO.

Institute of Cultural and Artistic Management. (2008). Propiedad intelectual: los derechos de autor en la industria musical. Universidad Europea Miguel de Cervantes.

Isaacson, W. (2011). Steve Jobs. Buenos Aires: Debate. 
López, J. A. (2014). El acceso a la información en la economía de red y su impacto en la industria discográfica. Revista Luciérnaga, 6(11), pp. 52-62.

Martínez, G. R. (2006). Sobre el derecho de autor. Bogotá: Universidad de la Sabana.

Moreau, F. (2013). The Disruptive Nature of Digitization: The Case of the Recorded Music Industry. International Journal Of Arts Management, 15(2), pp. 18-31.

Moyon, E. and Lecocq, X. (2010). Co-evolution between Stages of Institutionalization and Agency: The Case of the Music Industry's Business Model. Gestión Internacional, 14(4), pp. 37-52.

Ochoa, A. M. (2003). Músicas locales en tiempos de globalización. Bogotá: Norma.

Palmeiro, C. (2004). La industria discográfica y la revolución digital. Buenos Aires: Universidad de Buenos Aires.

Pucci del Río, P. (2008). La crisis del disco: un análisis estratégico bajo la perspectiva del marketing. Santiago: Universidad de Chile

Raposo, M. (2008). Nueva mirada sobre la industria de la música. Buenos Aires: Universidad de Palermo.

Ríos, W. (2011). Aspectos generales del derecho de autor y los derechos conexos. La Propiedad Intelectual en la Era de las Nuevas Tecnologías. Bogotá: Temis, Universidad de los Andes.

Rodríguez, P. (2019). La música un sector de crecimiento sin modelo de negocio. [Blog]. Telos. Recuperado de: https:// telos.fundaciontelefonica.com/la-cofa/la-musica-unsector-en-crecimiento-sin-modelo-de-negocio/ 
Rubio Tigasi, D. F. y Rivadeneira Suarez, F. J. (2019). Los mecanismos que el Código Ingenios establece para garantizar los derechos de autor en el comercio electrónico ecuatoriano. (Tesis de titulación). Quito: UCE.

Yudice, G. (2007). Nuevas tecnologías, música y experiencia. Barcelona: Gedisa.

Zermeño Flores, A. I., Fernández Reyes, A., Navarrete Vega, M. A. and Andrade, G. M. (2018). Vulnerabilidad simbólica en los jóvenes: la amenaza potencial de la industria musical digitalizada. Culturales, 6. DOI: http://dx.doi. org/10.22234/recu.20180601.e366

Received: $16 / 04 / 2020$

Approved: 30/07/2020

Juan Sebastián Aguirre Navarrete: Independent legal researcher

Email: juansebas131201@hotmail.com

City: Quito

Country: Ecuador 
